\title{
Management by objectives in relation to employees' personality types in Egyptian hotels
}

\author{
Moataz bellah Farid \\ Hotel Studies Department, \\ Suez Canal University
}

\author{
Haitham El-Sawalhy \\ Hotel Studies Department \\ University of Sadat City
}

\begin{abstract}
In order to increase organizations' productivity, managers focus on employees' creativity in setting and achieving forward-looking goals. This approach is known "Management by objectives" (MBO), which requires every department manager to set specific measurable goals with each employee and discuss the result toward the previously set goals. On the other hand, every employee has a unique personality that differentiates him from others. Hence, understanding the employee personality gives clues about how he acts and feels in various situations. Therefore, to manage people effectively, it is helpful to understand their different personalities for placing them into their suitable jobs and to understand how they can set their specific goals. This research aims at investigating the influences of personality types on MBO in the hotels industry. A survey method was used to collect practical data from 229 employees in 31 five star hotels in Greater Cairo; the obtained data was analyzed statistically. The research revealed that there are two personality types had positive influences on MBO dimensions. The research recommends that hotels should study employees' personality types to be able to create teams of personality types that can positively influence MBO.
\end{abstract}

Keywords: Management by objectives- personality types - DISC model

\section{Introduction}

MBO is the process whereby the performance goals and objectives are set by each subordinate in collaboration with his superior at the start of the appraisal period (Armstrong, 2006). This Philosophy is effective, as it is result oriented, emphasizes accomplishments rather than inputs, encourages participation at all levels of an organization (Holbeche, 2004). On the other hand, the employee's personality has a strong effect on his behavior particularly in tasks that involve a lot of autonomy or freedom, personality tends to exert a strong influence on work behavior (Klassen, 2006).

\section{Literature review}

\section{MBO}

Although several authors discussed the organizations' human resource handling approaches, still the most famous theories in this field were by Douglas McGregor in his book "The Human Side of Enterprise". He developed two connected theories ( $\mathrm{X}$ and $\mathrm{Y}$ ) for describing how the organization handles their employees; Theory X: predominated in the business world through the first decades of the 20th century. It was considered as a hard approach for handling human resource, as it aimed to deal with employees as just a factor like any other factor in the input-output equation, they need to be managed and exploited efficiently and tightly. Besides, it assumed that employees are reluctant to fulfill their jobs' obligations and continuously trying to find ways to avoid work or reduce their efforts. The opposite extreme of "X" was theory $\mathrm{Y}$, which explained the human resource soft approach, as it emphasizes that employees are not like any other resources, it is simply the organizations' creative resource. Hence, theory Y focused on strategies used for gaining commitment by informing employees about the company's mission, values, plans, and trading conditions, i.e. involving them in deciding how tasks should be carried out and grouping them in teams that work without strict supervision (Boxall et al., 2007).

Based on Y theory and other theories that defend the right of human resource to think, learn and react, the term "Management by Objectives" emerged (Tahir et al., 2008). It was first used by Peter Drucker in his book 'The Practice of Management', then it has been further updated by several researchers, among them Douglas McGregor, George Odiorne, and John Humble(Armstrong, 2006). Simply, MBO is a 
management approach that encourages the manager and his/her subordinate set objectives to be accomplished within a set period (Antoni, 2005). Again, MBO is a systematic and organized approach that allows both managers and employees to focus on achievable goals and to attain the best possible results from the organizations' available resources (Paul, 1997). Afterwards, MBO has been developed to be a practice of a larger management pattern called "participatory management" or "consultative management", which is a type of management in which employees at all levels are encouraged to contribute ideas towards identifying and setting organizational-goals, problem solving, and other decisions that may directly affect them (Dahlsten et al., 2005).

The main principle behind MBO is to assure that all the organizations' employees have a clear understanding of their objectives, well awareness of their roles and responsibilities. Hence, the subordinates are then held directly responsible for achieving their plans, which on turn achieve those of the organization (Concepcion, 2008).Based on that, MBO has several advantages; i.e. it encourages managers and employees to be committed to specific achievements by focusing on results and to gain better employees' commitment, control and coordination toward goal accomplishment (Cao et al., 2009). Moreover, MBO increases employees' loyalty, reduces turnover rates and helps them to see their strengths and weakness points in operation on a specific objective. In addition, it helps the organization to anticipate change and to delineate concrete measurements that will clarify goals achievement rates (Caiand $\mathrm{Hu}, 2005$ ).

To achieve its goals, MBO needs to be deployed via a system that permits mutual effective communication between managers and subordinates; such a system consists of six steps: (1)Set organization's goals, based on organizations strategic planning, (2) Set departmental goals, (3) continuous monitoring performance and progress, (4) performance evaluation, (5) reward performance (Drucker, 1954). The following figure shows the sequence of the five-step MBO process

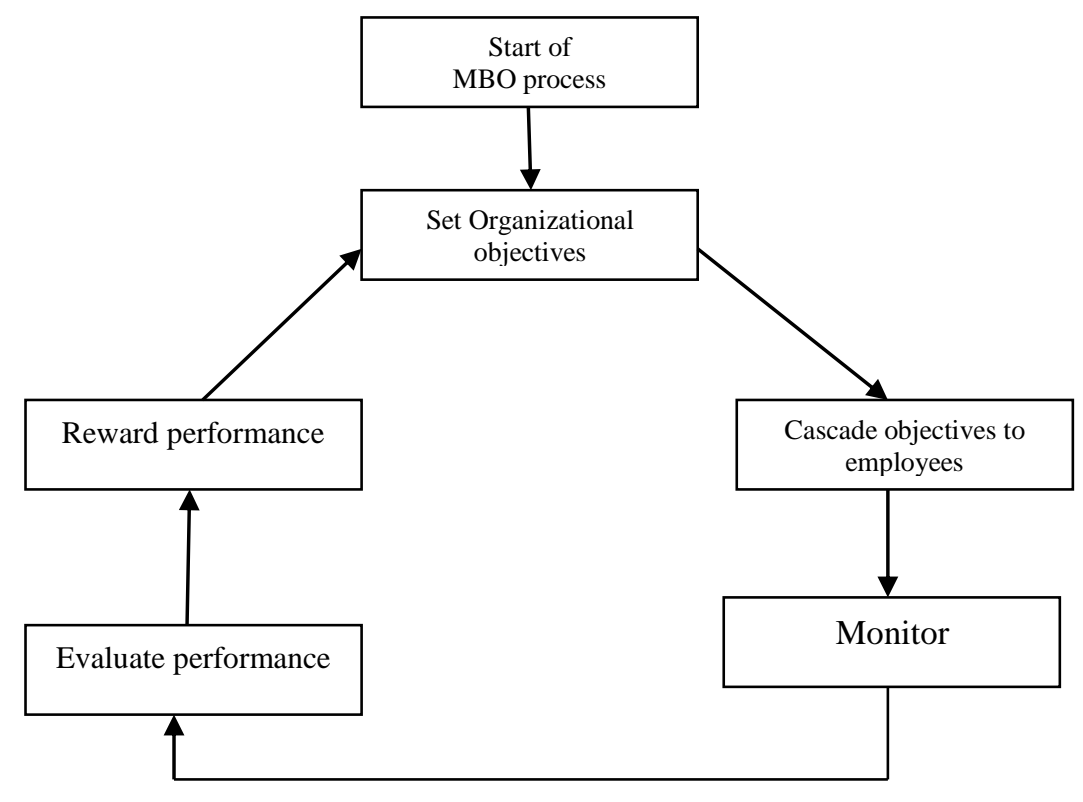

Figure (1): the five-step MBO process

(Drucker, 1954)

According to Drucker (1980), there are four basic dimensions to be watched carefully to avoid MBO traps and to help the organization stay on the right track: First is to ensure the suitable atmosphere between managers and subordinates which is based on trust, second is to get managers and employees participating to put, implement and achieve their goals, third is to ensure their commitment to achieve the in advance set goals, finally is to focus on the result, not on the activity only by continuously monitoring performance feedback. 


\section{Personality types}

The starting point of understanding people is to realize and accept that people are not the same (Klassen, 2006). However, Difference is not bad, but a lack of understanding others can cause real problems such as tension, disappointment, unmet expectations and poor communication (McLean, 2004). In hopes of understanding different types of personalities, several studies have discussed personality classification and many psychologists and scientists have explored behavioral patterns. Most notably Hippocrates, began to recognize and categorize differences in behavior that seemed to follow a certain pattern (Scott et. al., 2004).

In his book "The Emotions of Normal People", William Marston developed DISC assessment model as one of the methods used to characterize people's personality. He explained that human behavior is as a reaction to other people, situations, and events in the person's environment. Hence, DISC is a practical way to understand people in the common settings of everyday's' life, since then, DISC model has become one of the easiest and classic models used for understanding peoples' personalities(Klassen, 2006).

DISC model as away for analyzing peoples has several advantages that made it an effective tool for understanding personality types, i.e. it works as a positive tool to highlight a person in his strengths and address his blind spots. Moreover, it helps to recognize that each person has a unique blend of all the major personality traits to a greater or lesser extent, hence, to recognize that behavioral patterns are fluid and dynamic as a person adapts to his environment (Scott et. al., 2004).

DISC model is based on two fundamental elements about how people normally behave: a) person's "internal motor" which expresses peoples' paces, and was sorted to two types: outgoing or reserved, b) person's "external focus" which expresses peoples' priorities, and was sorted to two types, task oriented and people oriented (Marston, 1928). figure (2)shows the two elements

$$
\text { Internal motor }
$$

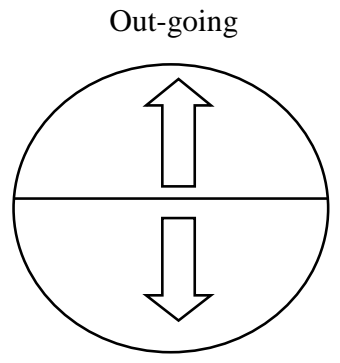

Reserved
External focus

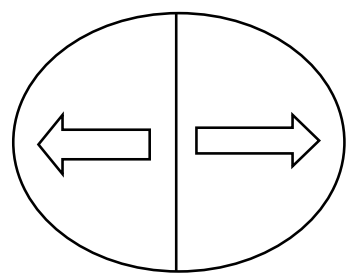

People-oriented

Figure (2): Elements of DISC model (Marston, 1928)

Based on these two elements, there are four behavioral tendencies helps in characterizing people: outgoing, reserved, task oriented and people oriented. All people have some of these tendencies in different situations and at different times. However, most of them have one or two of these tendencies describing their everyday behavior and the other tendencies usually do not fit them well and may even seem "abnormal" to their behavior. Merging these four tendencies in one circle shapes four basic personality types (figure 3): A) "Dominance" (D) is for Outgoing and Task-oriented (upper left quadrant),b) "Influence" (I) is for Outgoing and People-oriented (upper right quadrant), c)"Steadiness" (S) is for Reserved and People-oriented (lower right quadrant), and d) " Conscientiousness" (C) is for Reserved and Task-oriented (lower left quadrant).The descriptive terms will begin with D, I, S and C. Thus, the term "DISC" was introduced (Marston, 1928). 


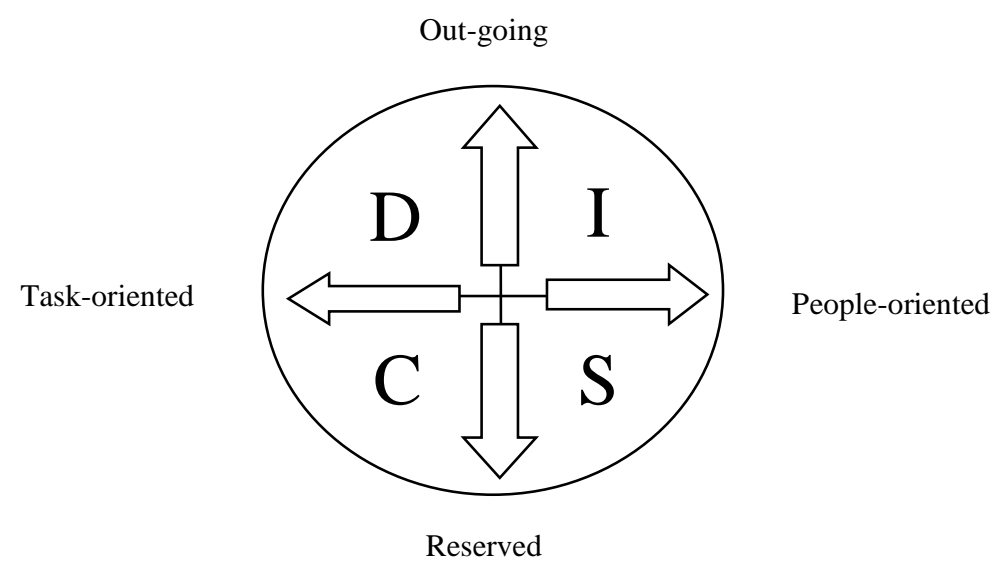

Figure (3): The four basic quadrants of DISC model behavior circle

(Marston, 1928)

Based on figure (3), there are four types of people are motivated by four intrinsic behavioral patterns.

- Dominant (Driving-Doer): is for powerful, strong and assertive people who tend to be independent and results driven. They always enjoy challenges, taking action and getting to the bottom line as quickly as possible and making it happens. They always focus on respect and results.

- Inspiring (Interesting-Interactive): refers to social and communicative people who are out going, sharing thoughts, participating on teams, and entertaining and encouraging others. They always focus on admiration and recognition

- Supportive (Steady-Stable): is for patient, persistent, and thoughtful people who tend to be supportive, cooperative and helpful to others. They prefer being behind the scene, working inconsistent ways. They are often good listeners and avoiding change and conflict. They always focus on friendship and appreciation.

- Cautious (Competent-Careful): is for people who check for details and quality and cares for accuracy. They always focus on trust and integrity (Scott et. al., 2004).

Afterwards, many tests existed under the name "DISC test", these tests were considered as personal assessment tools marketed by various psychological consulting companies for use by human resources departments, each of them with their own differences. These tests aim at sorting personality types' using survey questions, psychometric tests and situational cases to analyze persons types based on DISC traits. It always produces a report about the person's type and his main behavioral traits, which helps to improve employees' productivity, teamwork and communication (Inscape Publishing, 2005).

\section{Research objectives}

For the purposes of the study, the following objectives are formulated:

- Investigating the influences of personality types on MBO in the hotels industry;

- Identifying the most common personality type that exists in the hotels industry;

- Illustrating to what extent hotels are implementing MBO approach;

\section{Research hypotheses}

The research hypothesizes the following Hypotheses (Hs):

- There is a significant relationship between personality types and MBO.

- Personality types influence MBO dimensions.

\section{Conceptual framework}

The research suggested the following framework to examine the relationship between DISC personalities and $\mathrm{MBO}$ (figure 4) 


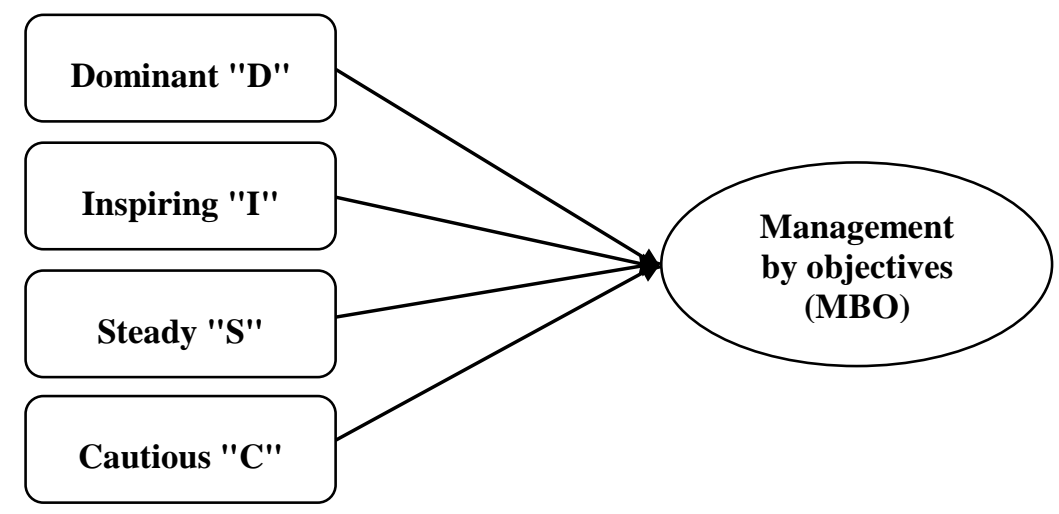

Figure (4): conceptual framework: DISC personalities and MBO

\section{Research Methodology}

A survey method was used to collect practical data, a questionnaire directed to 229 employees in 31 five star hotels in Greater Cairo. The questionnaire is composed of 3 parts. The first part includes 5 questions related to respondents personal data, the second part was a DISC test by Rosenberg and Silvert (2013) to sort respondents personality types according to DISC model, and the third part composed of 4 constructs asking for the required dimensions for applying MBO (trust - participation - commitment - feedback). These dimensions used a five point likert-type scale ranging from " $1=$ strongly disagree" to " $5=$ strongly agree" to score the responses. The obtained data was analyzed statistically by Statistical package for social sciences program "SPSS" 20 to obtain descriptive analysis and to calculate reliability and validity analysis, Spearman correlation analysis and regression linear analysis.

To test the influence of personality types on $\mathrm{MBO}$, a regression equation was established as follow:

$$
\mu \mathrm{Y}=\alpha+\beta 1 \mathrm{X} 1+\beta 2 \mathrm{X} 2+\beta 3 \mathrm{X} 3+\beta 4 \mathrm{X} 4
$$

Where; $\mu \mathrm{Y}=\mathrm{MBO}, \alpha=$ Constant, $\mathrm{X} 1=$ Dominant, $\mathrm{X} 2=$ Inspiring, $\mathrm{X} 3=$ Steady, $\mathrm{X} 4=$ Cautious

\section{Results and Discussion}

\section{Reliability and Validity}

To measure the internal consistency of the study instrument, Cronbach's Alpha was used to calculate the reliability of the questionnaire. Besides, the validity of the findings was calculated (Table 1).

Table 1: Coefficient of reliability and validity of the MBO constructs

\begin{tabular}{|l|l|c|c|c|}
\hline No. & \multicolumn{1}{|c|}{ Constructs } & $\begin{array}{c}\text { No. of } \\
\text { items }\end{array}$ & $\begin{array}{c}\text { Cronbach's } \\
\text { Alpha }\end{array}$ & Validity \\
\hline 1 & Trust between superior and subordinates & 5 & .95 & .974 \\
\hline 2 & Participation in setting objectives & 5 & .96 & .979 \\
\hline 3 & Commitment of subordinates to achieve objectives & 6 & .96 & .979 \\
\hline 4 & Feedback between superior and subordinate & 5 & .93 & .964 \\
\hline \multicolumn{2}{|r|}{ Overall Total Scale } & 21 & .97 & .984 \\
\hline
\end{tabular}

Table (1) indicated that the coefficient of Cronbach's Alpha for the constructs of was (97\%); the overall validity was (98\%). These results assured that the instrument is reliable; while Cronbach's Alpha of the used DISC test was not calculated as it is previously examined and approved by other researchers (Rosenberg and Silvert, 2013). 


\section{Descriptive Statistics}

The demographic data, personality types of the respondents and the implementation of management by objectives approach in the hotels of the study were organized and tabulated by using frequencies, percentage, mean scores and standard deviation.

\subsection{Demographic data of the respondents}

The respondents' demographic profile is shown in table (2) as follow:

Table 2: The respondents' demographic profile

\begin{tabular}{|c|c|c|c|}
\hline Demographics & $\begin{array}{l}\text { Characteristics and } \\
\text { Classification }\end{array}$ & $\begin{array}{l}\text { Frequency } \\
\text { (N) }\end{array}$ & $\begin{array}{c}\text { Percentage } \\
(\%)\end{array}$ \\
\hline \multirow{2}{*}{ Gender } & $\begin{array}{l}\text { Male } \\
\text { Female }\end{array}$ & $\begin{array}{c}212 \\
17\end{array}$ & $\begin{array}{c}92.6 \\
7.4\end{array}$ \\
\hline & Total & 229 & 100 \\
\hline \multirow[t]{2}{*}{ Age } & $\begin{array}{l}\text { Below } 30 \text { years } \\
30-45 \text { years } \\
\text { Above } 45 \text { years }\end{array}$ & $\begin{array}{c}81 \\
117 \\
31\end{array}$ & $\begin{array}{l}35.4 \\
51.1 \\
13.5\end{array}$ \\
\hline & Total & 229 & 100 \\
\hline \multirow[t]{2}{*}{ Educational level } & $\begin{array}{l}\text { College graduate } \\
\text { Postgraduate }\end{array}$ & $\begin{array}{c}202 \\
27\end{array}$ & $\begin{array}{l}88.2 \\
11.8\end{array}$ \\
\hline & Total & 229 & 100 \\
\hline \multirow[t]{2}{*}{ Position } & $\begin{array}{l}\text { High management } \\
\text { intermediate level/ supervisor } \\
\text { Operational level }\end{array}$ & $\begin{array}{c}36 \\
76 \\
117 \\
\end{array}$ & $\begin{array}{l}15.7 \\
33.2 \\
51.1 \\
\end{array}$ \\
\hline & Total & 229 & 100 \\
\hline \multirow[t]{2}{*}{$\begin{array}{c}\text { Work } \\
\text { Experience }\end{array}$} & $\begin{array}{l}\text { Less than } 5 \text { years } \\
5 \text { - } 10 \text { years } \\
\text { More than } 10 \text { years }\end{array}$ & $\begin{array}{l}72 \\
95 \\
62\end{array}$ & $\begin{array}{l}31.4 \\
41.5 \\
27.1\end{array}$ \\
\hline & Total & 229 & 100 \\
\hline
\end{tabular}

Table (2) illustrates that Out of 229 respondent, 212 respondents (92.6\%) are males while the remaining 17 respondents $(7.4 \%)$ are females. Among these respondents 81 respondents $(35.4 \%)$ are below 30 years old, 117 respondents (51.1\%) are from 30-45 years old and 31 respondents (13.5\%) are above 45 years old. In terms of educational level, the majority of the respondents are college graduates $(88.2 \%)$ while $11.8 \%$ are postgraduates. According to the current position, about $15.7 \%$ of respondents are of high-management level, 76 respondents $(33.2 \%)$ are inter-mediate level/ supervisors and 117 respondents $(51.1 \%)$ are operational level. Regarding work experience, about 72 respondents (31.4\%) have work experience of less than 5 year, while 95 respondents $(41.5 \%)$ from 5 to 10 years and 62 respondents $(27.1 \%)$ more than 10 years.

\section{Personality types}

Table (3): Personality types of the respondents

\begin{tabular}{|c|l|c|c|}
\hline No. & \multicolumn{1}{|c|}{ Personality type } & $\begin{array}{c}\text { Frequency } \\
(\mathbf{N})\end{array}$ & $\begin{array}{c}\text { Percentage } \\
(\boldsymbol{\%})\end{array}$ \\
\hline 1 & Dominant & 44 & 19.2 \\
\hline 2 & inspiring & 38 & 16.6 \\
\hline 3 & Steady & 78 & 34.1 \\
\hline 4 & Cautious & 69 & 30.1 \\
\hline \multicolumn{2}{|c|}{ Total } & 229 & 100 \\
\hline
\end{tabular}

Table (3) shows respondents Personality types' according to the findings of the used DISC test, the table shows that about $19.2 \%$ of respondents (44) are dominant type "D" , 38 respondents (16.6\%) are Inspiring 
type "I", while 78 of them (34.1\%) are Steady type "S" and 69 respondents (30.1\%) are Cautious type "C". This finding indicates that there is a variety of personality types in the study sample.

\section{The implementation of MBO in the hotels of the study}

The mean scores and standard deviation are calculated to illustrate to what extent hotels are implementing $\mathrm{MBO}$ approach. Table (4) indicates that the overall mean of implementing $\mathrm{MBO}$ is $3.61(\mathrm{SD}=.922)$.

Table 4: The implementation of MBO

\begin{tabular}{|c|l|c|c|}
\hline No. & \multicolumn{1}{|c|}{ Statement } & Mean & Std. deviation \\
\hline 1 & Trust between superior and subordinates & 3.84 & 1.025 \\
\hline 2 & Participation in setting objectives & 3.24 & 1.147 \\
\hline 3 & $\begin{array}{l}\text { Commitment of subordinates to achieve } \\
\text { objectives }\end{array}$ & 4.00 & .899 \\
\hline 4 & Feedback between superior and subordinates & 3.36 & 1.065 \\
\hline \multicolumn{2}{|c|}{ Overall Mean } & 3.61 & .922 \\
\hline
\end{tabular}

Note: Scale range from " $1=$ strongly disagree" to " $5=$ strongly agree"

Based on presented data, the hotels of the study are implementing MBO approach but this implementation is not fully integrated; since commitment of subordinates to achieve setting objectives obtained the higher mean score (4.0) while participation in setting objectives obtained the lower mean score (3.24). Trust between superior and subordinates was (3.84) and feedback between superior and subordinates was (3.36). According to this finding, MBO implementation needs more improvement especially in dimensions of workforce participation and feedback.

\section{Correlation analysis between variables of the study}

This section discusses the coefficient of correlation between personality types and MBO in hotels. These relationships illustrated in table (5):

\section{The relationship between personality types and MBO}

To test the first hypothesis (H1) which says, "There is a significant relationship between personality types and MBO", the Spearman's correlation was used to measure this relationship.

Table 5: The relationship between personality types and MBO

\begin{tabular}{|c|c|c|c|c|}
\hline \multirow{3}{*}{$\begin{array}{l}\text { Spearman's } \\
\text { rho }\end{array}$} & Variables & & Personality types & MBO \\
\hline & Personality types & $\begin{array}{l}\text { Correlation } \\
\text { Sig. (2-tailed) } \\
\text { N }\end{array}$ & $\begin{array}{l}1.000 \\
229\end{array}$ & $\begin{array}{l}.191 * * \\
.004 \\
229\end{array}$ \\
\hline & $\mathrm{MBO}$ & $\begin{array}{l}\text { Correlation } \\
\text { Sig. (2-tailed) } \\
\mathrm{N}\end{array}$ & $\begin{array}{l}.191 * * \\
.004 \\
229\end{array}$ & $\begin{array}{l}1.000 \\
229\end{array}$ \\
\hline
\end{tabular}

According to table (5), a highly positive Spearman's correlation (0.191) was obtained between personality types and MBO. This finding indicated significance at less than (0.04) level. Also, the correlation was relatively high, as cleared in table (5). Therefore, the results were significant; hence, the findings mean that the (H1) was supported. 


\section{The relationship between "Dominant" type and MBO}

To calculate the correlation between "Dominant" type of personality and MBO, the spearman correlation was used.

Table (6): The relationship between "dominant" type and MBO

\begin{tabular}{|c|l|l|r|r|}
\hline \multirow{4}{*}{$\begin{array}{c}\text { Spearman's } \\
\text { rho }\end{array}$} & Variables & & "Dominant" type & MBO \\
\cline { 2 - 5 } & \multirow{3}{*}{ "Dominant" type } & Correlation & 1.000 & .043 \\
& & Sig. (2-tailed) & & .520 \\
& & N & 229 & 229 \\
\cline { 2 - 5 } & \multirow{2}{*}{ MBO } & Correlation & .043 & 1.000 \\
& Sig. (2-tailed) & .520 & 229 \\
\hline & N & 229 & \\
\hline$* *$ Correlation is significant at the 0.01 level (2-tailed).
\end{tabular}

The results obtained of table (6) cleared no significant relationship between the type "Dominant" and MBO because the Sig. value (.520) is more than 5\% level.

\section{The relationship between "Inspiring" type and MBO}

The Spearman's correlation was used to calculate the relationship between "Inspiring" type of personality and MBO (table7).

Table (7): The relationship between "Inspiring" type and MBO

\begin{tabular}{|c|c|l|c|c|}
\hline \multirow{4}{*}{$\begin{array}{c}\text { Spearman's } \\
\text { rho }\end{array}$} & Variables & & "Inspiring" type & MBO \\
\cline { 2 - 5 } & \multirow{3}{*}{ "Inspiring" type } & Correlation & 1.000 & $.163^{*}$ \\
& & Sig. (2-tailed) & & .014 \\
& & N & 229 & 229 \\
\cline { 2 - 5 } & \multirow{2}{*}{ MBO } & Correlation & $.163^{*}$ & 1.000 \\
& Sig. (2-tailed) & .014 & 229 \\
\hline & N & 229 & 29 \\
\hline
\end{tabular}

Table( ) 7 clarified a significant correlation at (0.01) level between the "Inspiring" personality type and MBO. This relationship is positive and The Spearman's correlation is (.163)

The relationship between "Steady" type and MBO

The Spearman's correlation was used to calculate the relationship between "Steady" type of personality and MBO (Table 8).

Table (8): The relationship between "Steady" type and MBO

\begin{tabular}{|c|c|l|c|c|}
\hline \multirow{4}{*}{$\begin{array}{c}\text { Spearman's } \\
\text { rho }\end{array}$} & Variables & & "Steady" type & MBO \\
\cline { 2 - 5 } & \multirow{3}{*}{ "Steady" type } & Correlation & 1.000 & -.119 \\
& & Sig. (2-tailed) & & .071 \\
& & N & 229 & 229 \\
\cline { 2 - 5 } & \multirow{2}{*}{ MBO } & Correlation & -.119 & 1.000 \\
& Sig. (2-tailed) & .071 & 229 \\
\hline & N & 229 & 2 Correlation is significant at the 0.01 level (2-tailed). \\
\hline
\end{tabular}

Table 8 cleared that there is no significant relationship between the "steady" personality type and MBO because the Sig. value (0.071) is more than 5\% level. 
The relationship between "Cautious" type and MBO

Table (9): The relationship between "Cautious" type and MBO

\begin{tabular}{|c|l|l|c|c|}
\hline \multirow{4}{*}{$\begin{array}{c}\text { Spearman's } \\
\text { rho }\end{array}$} & Variables & & "Cautious" type & MBO \\
\cline { 2 - 5 } & & Correlation & 1.000 & $.220^{* *}$ \\
& "Cautious" type & Sig. (2-tailed) & & .001 \\
\cline { 2 - 5 } & \multirow{3}{*}{ MBO } & Correlation & .229 & 229 \\
\hline & Sig. (2-tailed) & .001 & 1.000 \\
& N & 229 & 229 \\
\hline \multirow{2}{*}{$* *$ Correlation is significant at the 0.01 level (2-tailed). }
\end{tabular}

According to the following table (9), the relationship between the "Cautious" personality type and MBO is highly significant at 0.01 level. The Spearman's correlation is positive and strong (22\%).

The four above tables illustrate a significant correlation between "Inspiring" and "Cautious" personality types and MBO dimensions. According to (Scott et. al., 2004) who described every personality type, "Inspiring" type is promoter, charming, confident, optimistic and open minded; hence, he is able to be a problem solver and a team leader, and "Cautious" is analyzer, accurate, diplomatic and patient. Hence, he is able to maintain high standards, define, clarify, get information and test it correctly. On the other hand, "Dominant" and "Steady" had no significant correlation with MBO dimensions. As, "Dominant" is president spirit, competitor and self-starter; hence, he is able to keep pace with others and be challenge-oriented, and "Steady" is Non- demonstrative, hesitant and inflexible. Hence, he supports the leader but can't be a leader.

\section{The relationship between personality types and MBO dimensions}

Table (10) illustrates the coefficient of correlation between variables of the study that include personality types (dominant, inspiring, steady and cautious) and MBO constructs (trust, participation, commitment and feedback). The significant level of correlation can be explained as follow:

Table (10): The relationship between variables of the study

\begin{tabular}{|c|c|c|c|c|c|c|}
\hline \multirow{5}{*}{$\begin{array}{c}\text { Spearman's } \\
\text { rho }\end{array}$} & Variables & & Trust & Participation & Commitment & Feedback \\
\hline & $\begin{array}{l}\text { Dominant } \\
\text { (D) }\end{array}$ & $\begin{array}{l}\text { Correlation } \\
\text { Sig. (2-tailed) } \\
\text { N }\end{array}$ & $\begin{array}{l}-.042- \\
.523 \\
229\end{array}$ & $\begin{array}{l}.064 \\
.335 \\
229\end{array}$ & $\begin{array}{c}-.200-* * \\
.002 \\
229\end{array}$ & $\begin{array}{c}.233^{* *} \\
.000 \\
229\end{array}$ \\
\hline & Inspiring (I) & $\begin{array}{l}\text { Correlation } \\
\text { Sig. (2-tailed) } \\
\text { N }\end{array}$ & $\begin{array}{l}.136^{*} \\
.040 \\
229\end{array}$ & $\begin{array}{l}.145^{*} \\
.028 \\
229\end{array}$ & $\begin{array}{l}.170 * * \\
.010 \\
229\end{array}$ & $\begin{array}{l}.163^{*} \\
.014 \\
229\end{array}$ \\
\hline & Steady (S) & $\begin{array}{l}\text { Correlation } \\
\text { Sig. (2-tailed) } \\
\mathrm{N}\end{array}$ & $\begin{array}{l}.027 \\
.688 \\
229\end{array}$ & $\begin{array}{l}.142-* \\
.032 \\
229\end{array}$ & $\begin{array}{c}.183-* * \\
.005 \\
229\end{array}$ & $\begin{array}{l}.137-* \\
.038 \\
229\end{array}$ \\
\hline & Cautious (C) & $\begin{array}{l}\text { Correlation } \\
\text { Sig. (2-tailed) } \\
\text { N }\end{array}$ & $\begin{array}{l}.017 \\
.801 \\
229\end{array}$ & $\begin{array}{l}.316 * * \\
.000 \\
229\end{array}$ & $\begin{array}{l}.100 \\
.133 \\
229\end{array}$ & $\begin{array}{l}.285 * * \\
.001 \\
229\end{array}$ \\
\hline
\end{tabular}

Table (10) indicated a significant relationship between dominant personality type and commitment to achieve objectives. The correlation is negative and high (-20\%). In addition, there is a high significant relationship between dominant type and the feedback between superior and subordinates. The Spearman' correlation is positive and high $(23 \%)$. Also, there is a significant relationship between inspiring personality 
type and all MBO Dimensions (trust, participation, commitment and feedback), the correlation is positive $(13.6 \%),(14.5 \%),(17 \%)$ and $(16.3 \%)$. Moreover, there are a significant relationship between the steady personality type and commitment to achieve objectives, participation in setting goals and feedback. The correlation is negative $(-14.2 \%),(-18.3 \%)$ and $(-13.7 \%)$. Finally, the results indicated a significant relationship between the cautious personality type and participation in setting goals and feedback, the Spearman's correlation is positive and high (31.6\%) and (28.5\%). figure (5) indicates these correlations.

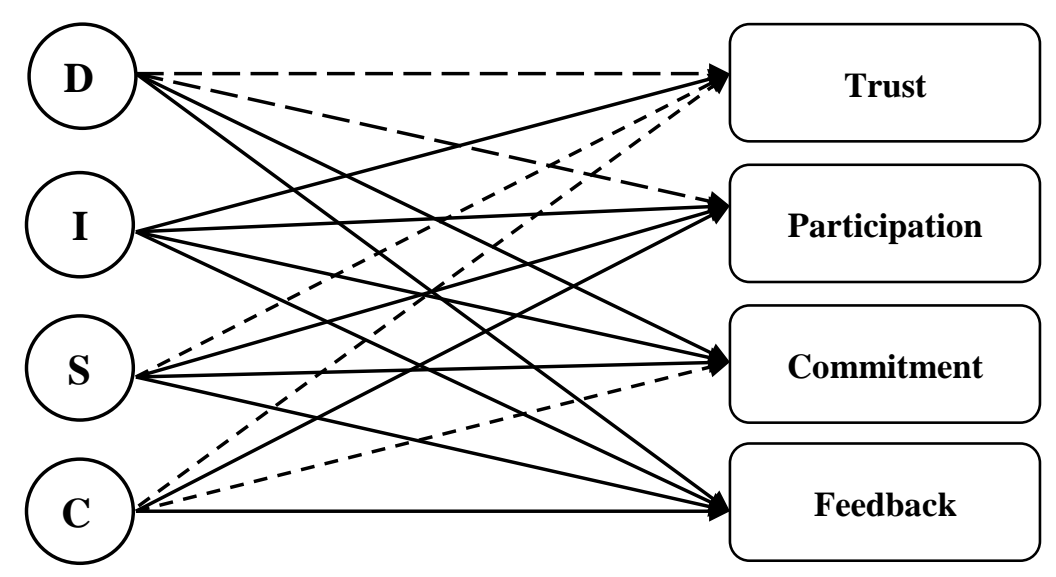

Figure (5): Correlation between the variables of the study

Figure (5) shows that every personality type has one or more non-significant correlation with MBO dimensions except "Inspiring" type who had fully acceptable significant correlations with all MBO dimensions. This means that "Inspiring" type is the most suitable type for applying MBO as he can act with all its dimensions.

\section{Regression analysis}

Multiple linear regression was used to test the prediction model of the study. Table (11) illustrates the multiple correlation coefficient $\mathrm{R}, \mathrm{R}^{2}$ and Durbin-Watson's coefficient.

Table (11):Model Summary of personality types and MBO

\begin{tabular}{|c|c|c|c|c|c|}
\hline Model & $\mathbf{R}$ & $\begin{array}{c}\text { R } \\
\text { Square }\end{array}$ & $\begin{array}{c}\text { Adjusted R } \\
\text { Square }\end{array}$ & $\begin{array}{c}\text { Std. Error of } \\
\text { the Estimate }\end{array}$ & $\begin{array}{c}\text { Durbin- } \\
\text { Watson(d) }\end{array}$ \\
\hline 1 & $.257^{\mathrm{a}}$ & .066 & .049 & .898 & 1.614 \\
\hline
\end{tabular}

a. Predictors: (Constant), Dominant, Inspiring, Steady, Cautious

b. Dependent Variable: MBO

Table (11) indicated that the Adjusted R Square value was (0.049) and Durbin-Watson's coefficient was (1.614). According to this finding, the model is acceptable as its value is lower than (2). Chatterjee and Simonoff (2013) mentioned that the value of Durbin-Watson's coefficient (d) always lies between 0 and 4 and, if (d) value is substantially less than 2, there is an evidence of positive serial correlation. Moreover, the following table (12) explains $\mathrm{F}$ test and $\mathrm{F}$ significance: 
Table (12): ANOVA ${ }^{\mathrm{a}}$ test

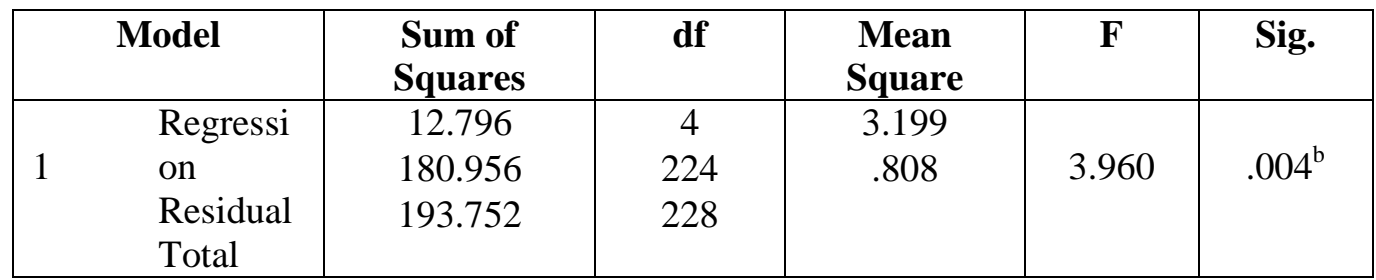

a. Dependent Variable: MBO

b. Predictors: (Constant), Dominant, Inspiring, Steady, Cautious

Table (12) cleared that $\mathrm{F}$ value was 3.960 and $\mathrm{F}$ significance was (0.004). Because the significance level is less than alpha, in this case assumed to be .05 , the model with variables dominant, inspiring, steady and cautious significantly predicted MBO. According to these findings, the second hypothesis $(\mathrm{H} 2)$ that says "Personality types influence MBO dimensions" was supported. Beta coefficient of regression was used to investigate the influences of each personality type on $\mathrm{MBO}$ as presented in table (13).

Table 13: Beta coefficients of personality types and MBO

\begin{tabular}{|c|c|c|c|c|c|c|}
\hline & \multirow[t]{2}{*}{ Model } & \multicolumn{2}{|c|}{$\begin{array}{l}\text { Unstandardized } \\
\text { Coefficients }\end{array}$} & $\begin{array}{l}\text { Standardized } \\
\text { Coefficients }\end{array}$ & \multirow[t]{2}{*}{$\mathbf{t}$} & \multirow[t]{2}{*}{ Sig. } \\
\hline & & B & Std. Error & Beta & & \\
\hline \multirow{5}{*}{1} & (Constant) & 2.626 & .515 & & 5.096 & .000 \\
\hline & Dominant & .057 & .069 & .068 & .828 & .408 \\
\hline & Inspiring & .168 & .072 & .172 & 2.318 & .021 \\
\hline & Steady & $-.010-$ & .061 & $-.013-$ & $-.171-$ & .865 \\
\hline & Cautious & .164 & .059 & .208 & 2.783 & .006 \\
\hline
\end{tabular}

a. Dependent Variable: MBO

The previous table illustrated that "inspiring" and "cautious" personality types are significant and positively influences management by objectives. Therefore, the empirical model of the study can be written as follows:

$$
\begin{gathered}
\mathrm{MBO}=\alpha+\beta 1 \mathrm{X} 1+\beta 2 \mathrm{X} 2+\beta 3 \mathrm{X} 3+\beta 4 \mathrm{X} 4 \\
\mathrm{MBO}=2.626+0.172 \mathrm{X} 2+0.208 \mathrm{X} 4
\end{gathered}
$$

This means that 1 unit changes in inspiring (X2) personality type will influences MBO by 0.172 units with the other factors being constant. Also, changes in cautious (X4) personality type by 1 unit will cause a change in MBO by 0.208 units with the other factors being constant.

The previous three tables illustrate that although "Inspiring" and "Cautious" personality types had significant influences on $\mathrm{MBO}$ dimensions, composing a team of the four personality types can positively influence MBO. Moreover, the absence of "inspiring" and "cautious" personality types from any team will affect negatively MBO deployment.

\section{Testing hypotheses}

The study hypotheses were tested by measuring the relationships among the variables. Table (14clears the results of testing hypotheses and the correlation level between variables. 
Table (14): The results of testing hypotheses

\begin{tabular}{|c|c|c|c|c|}
\hline \multirow[b]{2}{*}{ Hypotheses } & \multicolumn{2}{|c|}{ Test } & \multirow[b]{2}{*}{ Sig. } & \multirow[b]{2}{*}{ Result } \\
\hline & $\begin{array}{l}\text { Spearman's } \\
\text { correlation }\end{array}$ & $\mathbf{F}$ & & \\
\hline $\begin{array}{l}\text { H1: There is a significant } \\
\text { relationship between personality } \\
\text { types and MBO. }\end{array}$ & $0.191 * *$ & -- & 0.004 & Supported \\
\hline $\begin{array}{l}\text { H2: Personality types influence } \\
\text { MBO dimensions. }\end{array}$ & -- & 3.960 & 0.004 & Supported \\
\hline
\end{tabular}

According to table (14), the two hypotheses of the study are supported. The Spearman's correlation was used to test the first hypothesis (H1) that says "There is a significant relationship between the personality types and MBO". The Spearman's coefficient was 0.191 and the correlation was highly significant $(0.004)$. The, multiple linear regression was used to examine the second hypothesis (H2) that says "Personality types influence MBO dimensions ". From ANOVA test F value was 3.960 at a highly significant level (0.004).

\section{Conclusion}

Personality types influence MBO deployment in Egyptian 5 star hotels. The "Inspiring" and "Cautious" personality types had a positive effect on MBO dimensions rather than the "Dominant" and "Steady" personality types. Moreover, the "Inspiring" type is the most suitable type for applying MBO as he can act with all its dimensions.

\section{Recommendation}

Human resource managements in Egyptian hotels should use DISC tests to sort employees' personality types as a step to create a team that can effectively deploy MBO in hotels. This team should contain "inspiring" and "cautious" personality types as they can positively affects MBO.

\section{References}

Antoni, C. (2005). Management by objectives - An effective tool for teamwork? Int. J. Human Res. Management., vol. 16 (2), P.P: 174-184.

Armstrong, M. (2006). A Handbook of Human resource management practice, 10th edition, Cambridge University Press.

Boxall, P.; Purcell, J. and Wright, P. (2007). The Oxford handbook of Human resource management, Oxford University press.

Cai, Z. and Hu, J.H. (2005). Application of management by objective to drug administration, Pham, Care Res., Vol.5(4), P.P: 345-348.

Cao, Y.; Xu, T.; Zhou, Y.; Zheng, W. and Piao Z (2009). Power distribution reliability management by objective based on GIS platform. 1st International Conference on Information Science and Engineering (ICISE), Hong Kong.

Chatterjee, S. and Simonoff, J., (2013). Handbook of Regression Analysis, John Wiley and Sons.

Concepcion BCM (2008). Management by objectives needs to be applied with creativity and conceptual clarity. ACIMED, Vol. 18(6), p.p 4:11

Dahlstenl, F.; Styhre, A. and Williander, M. (2005). The unintended consequences of management by objectives: The volume growth target at Volvo Cars, Lead. Org. Dev. J., Vol. 26(7), P.P.: 529-541.

DeVellis, R. F. (2012). Scale development: Theory and applications, Los Angeles: Sage, pp. 109-110.

Drucker, P. (1954). The Practice of Management. Harper and Row, 1st ed, New York,

Drucker, P.F. (1980). Managing for Result. Motivation for Manager, Harvard Business Review.

Holbeche, L. (2004). How to make work more meaningful. Personnel Today, vol.26. p.p. 20:33

Inscape Publishing (1996). The Personal Profile System and Models of Personality: Research Report 
Inscape Publishing (2005). DISC Validation: The Personal Profile System and Models of Personality: Research Report

Klassen, P.T. (2006). Style insights - DISC, English V, Vol.12 (2), p.p: 25:32

Marston, W.M. (1928) Emotions of Normal People. RoutledgeCo., London.

Rosenberg, M. and Silvert D. (2013). Taking Flight: Master the DISC Styles to Transform Your Career, Your Relationships...Your Life. Upper Saddle River, New Jersey: FT Press.

McLean, E.M. (2004). Examining the Relationship between Individuals' Creative Products and their Creativity Styles. Unpublished Master's Thesis, Buffalo State - State University of New York, Buffalo, NY.

Paul, B. (1997). Management by objectives, New Delhi: Tata McGraw Hill Publishing.

Scott, G.; Leritz, L.E. and Mumford, M. (2004) The Effectiveness of Creativity Training: A Quantitative Review, Creativity Research Journal, Vol. 16, p.p: 361-88.

Tahir, Q. M.; Shafkat, K. A. and Mohammed K. (2008). Management by objectives, an effective tool for organizational performance: a case study of Pakistani industries, Proceedings of ASBBS (15)

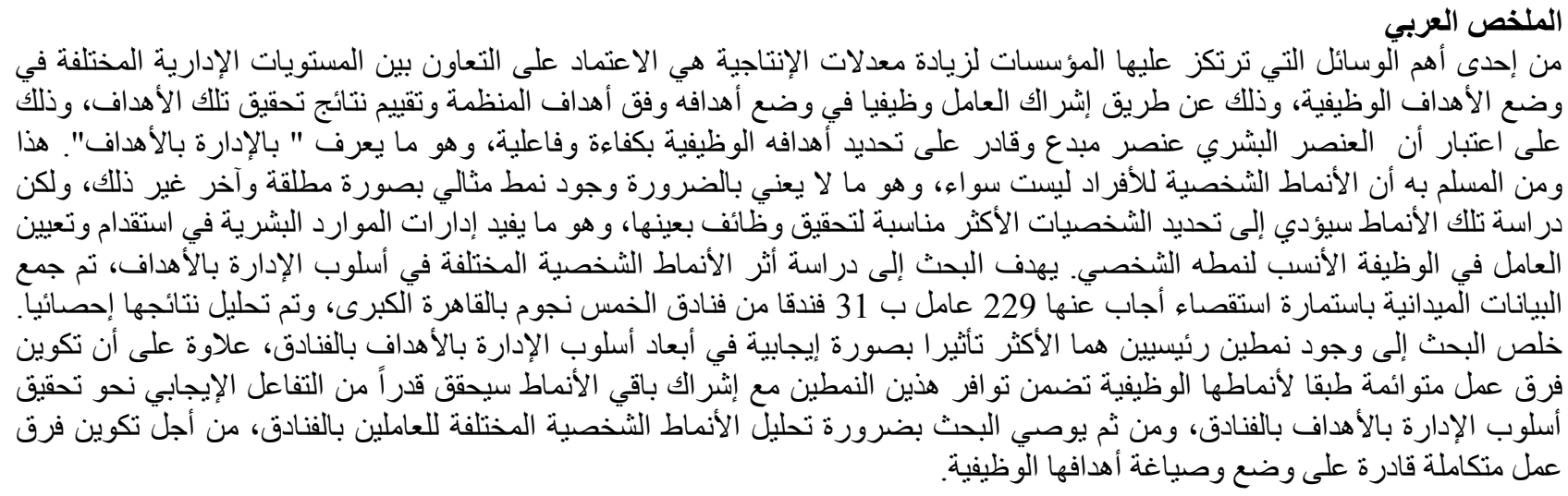

